\title{
Improving My Students' Writing Skill: An Intensive Course for ESL Learners by Using Process-Approach to Writing with the Assistance of Computer Word Processor
}

\author{
Samir Al-Jumaily ${ }^{1}$ \\ ${ }^{1}$ Department of English Language, College of Arts \& Letters, Cihan University, Erbil, Kurdistan Region, Iraq \\ Correspondence: Samir Al-Jumaily, roellandsplaats 41/3813HS/Amersfoort/The Netherlands. E-mail: \\ sbrother10@gmail.com
}

Received: October 22, 2014 Accepted: November 17, $2014 \quad$ Online Published: December 10, 2014

doi:10.5430/ijelt.v2n1p29 URL: http://dx.doi.org/10.5430/ijelt.v2n1p29

\begin{abstract}
This is a rapid and intensive course devoted to improve the struggling students' writing skill at Sur University College in the Sultanate of Oman. It follows the Process-Approach to writing with the assistance of computer word processing program. In the sense, dealing with writing as a step-by-step process. Word processing was mainly used in the revision phase. It made the revision process easier. This course is highly relevant to ESL/EFL learners. It's really organized after we realized that the students were hesitated, shy and frustrated when they were required to write in English. It is an interactive and integrated course in which the learners, in addition to writing, were supposed to master some vocabulary as well as grammatical rules. The main objective of the course is to motivate the learners not only to copy but to be creative and confident when tackling the writing craft. In achieving our objective, we wanted to show how computer can be a useful writing tool to improve students' writing skills. It's a challenge in which the learners were needed to work on generating ideas, organization and mechanism. We were determined to orient the students to use the computer word processing program with the perspective that confidently they will enjoy this experience. Therefore, they got the opportunity to practice and edit their writing in order to improve grammar, spelling and punctuation.
\end{abstract}

Keywords: ESL learner, Writing skill, Student, Computer Word Processor

\section{Introduction}

Writing is the process of using symbols to communicate ideas. It's a system/method of representing language in visual or tactile form. Writing is the $4^{\text {th }}$ language skill that learners need to work hard on to master. It's the mirror that reflects/shows one's knowledge about a language. Although it's highly necessary for everybody to be understood in speech, writing as such is at least as important as the ability to speak. It is an effective way of communicating with others by expressing thoughts, feelings and opinions. People usually wish to have their writing well-organized, clear and interesting. No one is born with good writing skill. This skill comes through practice and determination. Thus, writing is one of the most important ways of expressing thoughts and perspectives.

At schools, a student is often judged by the quality of his/her writing which is a vital criterion to assess one's knowledge and intellectuality. Students participating in this course and due to having limited knowledge about how to use and utilize the word processing device, they were provided by some instructions which aided and taught them how to edit and revise effectively. Accordingly, Moore (1987) has found that "students using word processing made more meaning-related changes in text than did those using pen and paper". Thus, teachers should encourage the excitement of writing, with the assistance of using word processing program, in their students by being interested and involved with the writing process their students use in schools.

Bello (1997) believes that writing enhances language acquisition as learners experiment with words, sentences, and large chunks of writing to communicate their ideas effectively and reinforce the grammar and vocabulary they are learning in class. Correct grammar, spelling and punctuation are key factors in the written communication system. It's a continuing process that enables learners to find the most effective and suitable language for expressing themselves. So, writing is a process; the more you practice it, the better your writing will be. 
Accordingly, a need felt to organize a writing course for struggling students at Sur University College-Sultanate of Oman using the Process-Approach to Writing with the assistance of word processing program. The main motive was when I started teaching skills of which writing was one in the language classroom, I immediately realized that the students were extremely demotivated whenever asked to write in English due to being shy and frustrated.

\section{The Effect of Word Processing on Students' Writing Quality}

Integrating technology in the writing process may result in having greater impact on the improvement of writing quality. Recent research findings confirm that the use of word processing has made tremendous changes in the curriculum and instructional methods. The word processing program is a helpful tool in improving students' writing. Eyres (2007: 210) assures that "There can be no doubt that the editing facility offered by computers has revolutionized our attitudes to mistakes." If students have access to computers at schools, computers will greatly be beneficial and supporting students' writing. Harmer (2001:261) assures and lists the main benefits of using a computer word processor as follows:

1. "A word-processing package removes the problem of poor handwriting that some students suffer from.

2. A word processing package allows the competent user to edit his or her material at great speed and with great facility.

3. Spellcheckers can ease the task of achieving correct spelling.

4. If students are working in groups, a computer screen can sometimes be far more visible to the whole group than a piece of paper might be."

Consequently, the use of word processing in students' writing has increasingly become popular. Graham (2008:6), for example, states seven ways of developing writers by using word processing facility:

1. Legibility of text,

2. Potential for publishing in variety of formats,

3. Ease of revision,

4. Fluent production of text (while composing, not taking, etc.),

5. Likelihood of supporting applications (for spelling, grammar, semantic mapping),

6. Portable, easy to replicate electronic text (easy to share and provide feedback; hard to lose), and

7. Potential for links to electronic source material.

In the stage of using the word processor for their writing, students could produce longer and higher quality writing compared with the stage of using pen or pencil and paper. This is why, nowadays, there is a great tendency and interest in using computer in the field of learning/teaching ESL.

In some universities, worldwide, it is obligatory to use the word processing program in language learning. ESL instructors, by their turn, have shown their interest in the effect and benefits of computers in the classroom. Therefore, this course has proved the utility of using the word processing program in improving students' writing skill in ESL classroom.

Although word processing has become a buzzword in the field of language learning/teaching, some researchers, like Cochran (1991:114), think it "doesn't improve the overall quality of students writing". This perspective really contradicts Eyres' (2007:210) when he insists that computer word processor is a very supportive and assistive tool in the writing process. It makes the chance available for the learner to correct his/her mistakes immediately. He adds "Getting my first word processor changed my life. ............... I could change things as much as I wanted and nobody need ever know. Now, I was worrying less about the state of my first draft and spending much longer on making the changes that let me say exactly what I wanted to." Generally speaking, the effect of the word processor was greatly positive on the quantity and quality of the students' writing in this course. So, throughout our experience since dealing with this course, it was easy for the teacher, me, to provide feedback on electronic text due to the great features and facilities that word processing program has and also enable teachers, in general, to add, insert, change, delete, etc. and easy for the learner to observe.

\section{The Process Writing Course}

Process Writing is the development of a document by using specific techniques and overlapping steps such as 
pre-writing, drafting, editing, revising and publishing. Writing is a challenging continuing process in one's native language or in a second language. Therefore, a particular strategy of several phases was implemented to achieve this course successfully. Moreover, the learners were provided with a guideline to follow and to know clearly all the steps required.

\subsection{Input or Pre-Writing}

It is the phase wherein the students begin by making up their minds about what to write and the form in which it is to be written. Here, the students practice different activities such as brainstorming, reading, listening, and quick writing. Brainstorming is an activity wherein the learners unleash the idea generating process. In this phase, the students tried to outline their ideas on paper in the form of a plan. Usually, writing involves a planning stage. Crystal (2006:127) confirms that in this stage "we organize our thoughts and prepare an outline of what we want to say. Even the shortest of messages requires a moment or two of planning." Therefore, learners needed to practice thinking which is a major factor. They were told to come up with as many ideas as possible on a given topic. They were also asked to search for information and details related to the main topic. In order to simplify things for the learners, they were provided with a statement (topic sentence) in order to list all the possible elements (reasons) to support the main topic sentence. They were getting together after they had been provided with specific texts to read and discuss and finally come up with ideas relevant to the main topic. The texts were really taken from books as well as local English newspapers. The type of reading practiced by the learners was interactive. They were also advised to learn by heart as much vocabulary as they could because words are the key stones of language. Building up language in one's head is like constructing a true building. The basic elements of a building are stones, and, as above mentioned, words are the stones of language. In order for a building to look amazing and attractive, it should be covered with some decoration which is really the finishing stage. Similarly, learning a language is not just mastering the words of that language, but words have to be set and organized in specific orders to be meaningful and grammatical (well-formed). This is what I was telling my students. Each group member then worked alone to compose a first draft, concentrating on getting ideas down on paper, without worrying about spelling or grammar at this stage.

\subsection{First Draft Writing}

This phase is known as the drafting stage. Drafting is simply the process of getting ideas down onto paper or screen. At the beginning, students were given some instructions to follow along with bringing to their attention that no perfect writing expected at this phase. It's a period of just discovering ideas, and the students' writing could be changed later on in the writing procedure. Thus, if a student missed important thoughts in the first draft, he could add them in a later draft. Two sets of skills were involved in this stage. The first is called compositional skills wherein the students practiced choosing the right words, sentences, and text structures as well as setting them out in a way that expresses the intended ideas. The second is called transitional skills usually involved in translating the words and sentences in the student's head into marks on the page or screen. These skills include handwriting, spelling and punctuation. "The value of the first draft is paramount; it is the clay from which the final draft is fashioned" (Eyres: 211). The time the students had got together, they worked in pairs or small groups. After they had got confident, they encouraged each other with constructive comments and questions as they sought better understanding of what each other was trying to write. The students needed no to spend too much time on the initial draft because the real work went into modifying and developing their texts through successive draft stages. In this phase and as per the guideline, the participants put and organized their ideas on paper. Their writing was focusing on the main idea. They were practicing peer evaluation. While they were doing that, I used to tour among the groups checking their writing and answering their questions. I decided not to interfere deeply in their writing at this phase following the dicto-comp techniques which is really a procedure intermediate between completely controlled writing exercises and completely free composition. Since the students' first language is Arabic, they were advised to use and consult Google Translator Dictionary to broaden their vocabulary; in the sense, a student may know a word in Arabic, but he/she doesn't know its meaning in English. So, he/she could get that by visiting and checking the above mentioned dictionary. Likewise, he/she can find the meaning of the English counterpart words he/she knows in the same dictionary. Moreover, students were advised not to over use a single word or item, but he/she should look for some other synonyms by using a printed dictionary or online resources. This would definitely result in developing their vocabulary. The students were also provided with some words and items relevant to the texts working on and to be included in their writing.

\subsection{Second Draft Writing}

The notion of writing should be supported with that of rewriting. "Any model of what happens when we write must take into account the act of revision- from the first stages of making notes, jottings, and headings, through various drafts, to the final version" (Crystal 2006: 127). 
This phase underpins the following two activities:

A- Revision: in this stage, the learners had to make some changes in the content or even to start over. They started reviewing the $1^{\text {st }}$ draft and looking for some traits of good writing by using the computer word processing program, but before doing that I used to check their writing using the editing marks and make the chance available for them to figure out their grammatical, spelling and punctuation mistakes by themselves through the use of the word processing program and to change them immediately by using spell and grammar checkers which effectively helped to reduce time and efforts. The spell and grammar check characteristics of the recent word processing program made it easier for language learners to spot their errors. Not only that, but it made the process of moving around words, sentences and paragraphs easier than that of writing on a piece of paper. It was extremely necessary at this phase to pay attention to ideas and organization. In the sense, to do the revision process by adding, removing, and re-ordering words to improve the quality of their writing. This was to check the strong and weak points in their writing.

B- Proofreading: in this stage, the learners reviewed the $1^{\text {st }}$ draft again in order to correct the mechanical errors and to check spelling, grammar, and punctuation. Students' frequent revision activities led to minor changes in spelling, grammar, addition, deletion, substitution and reordering words. In the writing workshops, the learners were informed that knowing a language means more than knowing only the words of that language. It could be easy for someone to memorize a whole dictionary of English language, but this will not give him the knowledge and ability to speak or write English efficiently or effectively. In other words, the learners needed to know about the structure of sentences and how to put words together to form well-formed and meaningful sentences. For example, although the following two sentences have the same words, they have different meaning due to the different positions occupied by the nouns in the following two sentences:

\section{Bob hit Bill.}

\section{Bill hit Bob.}

There are rules in everyone's grammar that govern and determine how morphemes and words must be combined to express a particular meaning.

After the draft was complete and the students started the revision process, they were supposed to ask themselves the following questions:

1. Does the draft make sense?

2. Does it reflect the writer's perspectives?

3. Has the structure of the text been maintained properly?

4. Has the draft followed the rules and conventions of Standard English?

Further, they used to get some instructions on some elements of writing such as description, definition, or coherence. Accordingly, the learners were practicing some form of related writing activity. In line with the strategy made, the $2^{\text {nd }}$ draft was collected, after got printed out, in order to provide the learners with our feedback after checking the overall idea of the content and/or make an outline of the main points. Moreover, I was providing them with some comments, written on paper, about the content such as positive reactions, questions and suggestions.

Due to the learners' culture and nature and in order to avoid embarrassment, student-teacher sessions were held individually about their papers at this phase. The purpose of such sessions was to ask them to summarize the main points of their papers and/or to respond to the remarks I had written on their $2^{\text {nd }}$ drafts. The principal concern was to discuss the content of their papers, and later on to discuss the form and structure of their writings which led to having some remedial classes in grammar.

After analyzing their grammatical errors and due to figuring out some common errors, a collective session was organized in which the learners got some instructions as well as practicing some activities. Meanwhile, the learners were asked to keep all their writing samples in a file in order to compare them later on with the final drafts and to check and assess the progress they achieved.

\subsection{The Final Draft}

This was the final phase of writing or typing the draft and considering the appearance and neatness as well as using the appropriate form to communicate ideas. It's also called the publication stage. As above mentioned, the final draft was submitted along with a file in which all the notes, lists, quickwrites, etc., as well as the previous drafts. The final draft was checked for all content and readability. In this final phase, a great progress was noticed and there was a positive difference and change in the students' attitudes toward writing. 


\section{Writing Topics}

Our strategic plan was to write three papers. Several topics had been suggested to write about. The participants agreed to write about:

1. Smoking,

2. Air Pollution, and

3. Global Warming.

It's worthy to mention that some other short writing assignments had been done by the learners in order to broaden their writing skills. They were practicing letter writing, email writing, memo writing, and instruction writing. They were provided with some texts to summarize and some pictures along with a set of questions to think about and answer. These assignments were kept with the learners hopefully to be submitted in the last week of the course for evaluation.

\section{Conclusion}

No hesitation to tell that my overall evaluation of this course was highly positive owing to the results arrived at. There was a great improvement in the students' writing quality particularly in the content, organization, vocabulary and grammar. It has been found that because the time of a regular writing class was limited, students didn't show enough interest in the writing activities. Therefore, they found this course is a great success due to having enough time which resulted in improving their writing skill greatly. This course outstandingly proved the impact of writing with word processing on both the composition process and the quality of the work produced by the students although they, at the beginning, reflected their personal nature and style of working to the word processing domain. The influence of word processing on the writing quality and revision strategies were positive and effective. It has been found that this practice was remarkably effective in improving the students' writing and could be rated five times greater than those written with pen and paper. The majority of the students were able to use the power of word processing facility to enhance their advantage which ultimately resulted in the creation of a reasonable successful piece of writing. Learners have noticed an overwhelming relation between computer use and the length and quality of their writing. The course was extremely beneficial to the learners, and teachers could make use of it as well. The utmost benefit of this course was the interaction between the learner and the teacher throughout the whole writing process. It is recommended to enhance such interaction by increasing the contact hours which will definitely result in a healthy class rapport in such a short-term course. It is also suggested to make the use of word processing as a mandatory part in the teaching/learning of writing in schools.

\section{Guideline}

The main purpose behind having good writing is to communicate ideas and information. If a person wants to be understood, his writing must be well-organized, clear and interesting. You should think about writing as step-by-step process. Therefore, in order to be a good writer, you have to follow the illustrations below and complete each step carefully.

Step 1 (pre-writing): take time to think about your ideas and ask yourself the following questions:

1. What do you want to say?

2. How do your ides relate to each other?

3. Do you need more information?

This step is called PRE-WRITING.

Step 2 (first draft): after pre-writing you should get your ideas on paper as fast as you can. Write about your ideas as completely as you can. Don't worry about making mistakes at this phase because you can correct them later on. This step is called the FIRST DRAFT.

Step 3 (revision): re-read (read again) your first draft. Make changes wherever necessary to improve the content, clarity, and style. Add and take out words. Show changes by using the editing marks below. This step is called REVISION.

Step 4 (proofreading): read your first draft again. Look for mistakes such as misspelling,

poor grammar, or punctuation errors. This is different from revising where you are trying to improve your work. 
Correct mistakes. Use editing marks to show corrections. This step is called PROOFREADING.

Step 5 (publication): copy your work so that it will be neat, errors free, easy to read and beautiful to look at. Make your work something you are proud of. Consequently, your readers will enjoy it better. This step is called PUBLICATION.

Table 1. The five steps in detail

The chart below shows the five steps of the writing process in detail. It helps you know what happens during each step.

\begin{tabular}{|c|c|}
\hline $\begin{array}{l}\text { STEPS IN THE WRITING } \\
\text { PROCESS }\end{array}$ & WHAT YOU DO DURING EACH STEP \\
\hline 1. PRE-WRITING & $\begin{array}{l}\text { *Brainstorm for ideas to write about } \\
\text { *Make a list of ideas } \\
\text { *Search for information and details } \\
\text { *Organize ideas and details around a main idea } \\
\text { *Outline important ideas and details }\end{array}$ \\
\hline 2. DRAFT & $\begin{array}{l}\text { *Use an organizer or outline to guide writing } \\
* \text { Get ideas down on paper (the } 1^{\text {st }} \mathrm{draft} \text { ) } \\
\text { *Stay focused on the main opinion }\end{array}$ \\
\hline 3. REVISION & $\begin{array}{l}\text { *Review the } 1^{\text {st }} \text { draft looking for traits of good writing } \\
\text { *Pay attention to ideas and organization } \\
\text { *Listen to how your writing sounds } \\
\text { *Add, remove, and re-order words to improve writing } \\
\text { *Use editing marks to show revisions }\end{array}$ \\
\hline 4. PROOFREADING & $\begin{array}{l}* \text { Review the } 1^{\text {st }} \text { draft correcting mechanical errors } \\
* \text { Check spelling, grammar, and punctuation } \\
* \text { Use editing marks to show corrections }\end{array}$ \\
\hline 5. PUBLICATION & $\begin{array}{l}\text { *Write or type the final draft } \\
\text { *Pay attention to appearance and neatness } \\
\text { *Use appropriate form to communicate your ideas }\end{array}$ \\
\hline
\end{tabular}

\section{References}

Bello, T. (1997). Improving ESL Learners' Writing Skill. Retrieved April 17, 2013 from www.ericdigest.org/1998-1/skills.htm. http://dx.doi.org/10.1.1.112.9315

Briggs, R. J., \& Daniela. S. (2002). Managing Effective Learning and Teaching. London: Sage Publications.

Cochran-Smith, M., Cynthia L. P., \& Jessica L. K. (1991). Learning to Write Differently. Norwood, NJ: Ablex.

Crystal, D. (2006). How Language Works. London: Penguin Books Ltd.

Doff, A. (2002). Teach English: A Training Course for Teachers. Cambridge: Cambridge University Press.

Eyres, I. (2007). English for Primary and Early Years. Los Angeles: Sage Publication.

Graham, S. (2008). The Power of Word Processing for the Students. Winconsin: Renaissance Learning Incorporation.

Harmer, J. (2001). The Practice of English Language Teaching ( $3^{\text {rd }}$ ed.) Essex: Pearson Education Limited.

Hornby, A. S. (2010). Oxford Advanced Learner's Dictionary of Current English. Oxford: Oxford University Press.

Moore, M. A. (1987). The Effect of Word Processing Technology in a Developmental Writing Quality, Attitude towards Composing, and Revision Strategies of Fourth and Fifth Grade Students. Dissertation Abstracts International 48, 635A. 
Simpson, Adam. (2012). A Process Approach to Writing. Retrieved May 12, 2014 from www.developingteachers.com/articles_tchtraining/pw1_adam.htm. http://dx.doi.org/10.2307/821728 